\title{
Global Constitutionalism: Editorial Introduction
}

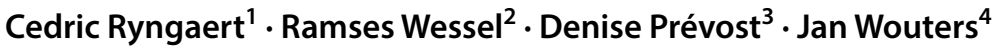

Published online: 22 August 2019

(c) T.M.C. Asser Press 2019

Over the past 20 years, the study of international law has been confronted with abundant attention being given to 'constitutionalism'. ${ }^{1}$ This has even given rise to the establishment of a brand new, interdisciplinary journal, Global Constitutionalism. ${ }^{2}$ The main reason for scholars' increased engagement with global constitutionalism was arguably that international law had changed, at least in the eyes of its observers. No longer was international law a law between states; it had become a law governing interactions within states. In particular, international law was viewed as having a clear impact on individuals, just like national law impacts on individuals. ${ }^{3}$ Examples include rules on counterterrorism, climate change, migration and refugees, health and food safety, trade or technical standards. The idea was that with the transfer of the regulation of these issues from the state to the global level-using a variety of formal and informal international cooperation forums 4 - constitutional safeguards (mainly in terms of rule of law principles) needed to be reassessed and perhaps recreated at different levels.

\footnotetext{
${ }^{1}$ E.g., Klabbers et al. (2009); Schwöbel (2011); Fassbender (2016); Peters (2006).

${ }^{2}$ Global Constitutionalism (Cambridge University Press), ISSN: 2045-3817 (Print), 2045-3825 (Online). In its own words, 'Global Constitutionalism (GlobCon) offers an interdisciplinary space for addressing the foundations, limitations and contestations of the principles and norms of political order and their dynamics over time on a global scale'.

${ }^{3}$ E.g., Peters (2008).

${ }^{4}$ See e.g., Pauwelyn et al. (2012, 2014); Oldani and Wouters (2018).
}

Cedric Ryngaert

c.m.j.ryngaert@uu.nl

Ramses Wessel

ramses.wessel@utwente.nl

Denise Prévost

denise.prevost@maastrichtuniversity.nl

Jan Wouters

jan.wouters@ggs.kuleuven.be

1 Utrecht University (RENFORCE Research Programme), Utrecht, The Netherlands

2 University of Twente, Enschede, The Netherlands

3 Maastricht University, Maastricht, The Netherlands

4 KU Leuven, Louvain, Belgium 
Moreover, as international law developed, it came to be increasingly seen as a coherent legal system governed by systemic, constitutional principles. ${ }^{5}$ Studies on global constitutional law, global administrative law, ${ }^{6}$ post-national rule-making, ${ }^{7}$ the exercise of public authority, ${ }^{8}$ or informal international law-making ${ }^{9}$ increasingly became a main focus of attention. Public international law was believed to have changed into international public law buttressed by an international community sharing a number of core values, such as the rule of law, human rights, accountability, transparency etcetera. ${ }^{10}$ This terminology underlined the more hierarchical and collective public dimension, as, e.g., manifested by norms of jus cogens or erga omnes obligations, rather than the original private or contract law dimension. ${ }^{11}$ Also, terms like law-making by international organizations, international legislation and multi-level regulation became more commonly used. ${ }^{12}$ A considerable number of international law scholars now think in terms of a global constitution, both in general terms or in relation to specific issue areas (e.g., the global economic constitution). ${ }^{13}$

The current issue features four articles which examine a particular field, issue, or source of international law through the prism of global constitutionalism. Drafts of these articles were presented at a workshop of the annual Ius Commune conference in Amsterdam on 29 November 2019. The workshop, entitled 'Taking Stock of Global Constitutionalism-To What Extent Did it Really Change International Law?', was organized by the Ius Commune research programme 'Constitutional Processes in the International Legal Order'.

The authors were requested to take four guiding questions into account:

1. How is 'global constitutionalism' defined, or how do you define it, in the context of the legal area which you examine? Are tensions between various conceptions of global constitutionalism discernible?

2. To what extent are 'multilevel' elements (global, regional, national) part of the approach to global constitutionalism? Is there tension between global constitutionalism on the one hand, and national or regional constitutionalism on the other, as exemplified in particular issue areas?

3. To what extent do the relevant developments in your area reflect global constitutionalism? What are their effects on the structure of the international legal system?

\footnotetext{
5 E.g., Benvenisti (2007).

6 E.g., Cassese (2005); Kingsbury, Krisch and Stewart (2005).

7 E.g., Krisch (2010).

8 E.g., von Bogdandy et al. (2010).

9 E.g., Pauwelyn et al. (2012). For a comparative overview between these main currents, see Duquet and Wouters (2014).

10 E.g., von Bogdandy et al. (2017).

11 E.g., de Wet and Vidmar (2012).

12 Alvarez (2006); Talmon (2005); Follesdal et al. (2008).

13 E.g., Joerges and Petersmann (2006).
} 
4. What actors and institutions steer the constitutionalization process? Does global constitutionalism entrench the power of particular actors?

Given the limited number of contributions, it is impossible to give methodologically valid answers of a general scope to these questions. Still, the contributions have generated some surprising insights into actual constitutionalization processes taking place in specific areas, as well as into the potential of global constitutionalism to reinvigorate stale areas.

To start with the latter, Craig Eggett relies on global constitutionalism 'to reignite the discussion on the nature and function of general principles of law', arguably the enfant pauvre of the sources of international law listed in Article 38 of the Statute of the International Court of Justice. Eggett argues that greater reliance on general principles of law could enhance the systemic coherence of international law, as such principles give shape to the underlying values and objectives underpinning the international legal system. Furthermore, general principles, which often have a procedural character, could strengthen the procedural framework governing international dispute settlement, and thus contribute to one of the core tenets of constitutionalism: the judicialization of international law. ${ }^{14}$

With respect to actual constitutionalization processes, Emily Sipiorski identifies rival conceptions of global constitutionalism that map onto the debate regarding the appropriate site of constitutional protections in a world governed at multiple levels. Zooming in on the area of investment protection, Sipiorski draws attention to conflicting economic-constitutional rights that are protected by both EU law and bilateral investment treaties. Theorizing a recent decision by the Court of Justice of the EU, which held dispute resolution provisions in international (bilateral) investment treaties (to the extent that they apply between EU Member States) to be incompatible with EU law, ${ }^{15}$ she discerns a tension between a 'global' constitutionalism and a European variant. Such a tension had in fact previously come to the fore before the Court of Justice in the Kadi case, which pertained to perceived conflicts between UN Security Council counterterrorism resolutions and EU constitutional values. ${ }^{16}$ In the investment law context, the international and EU conceptualizations of constitutionalism both give pride of place to rule of law protections, but they opt for divergent dispute resolution procedures (international versus domestic ones); in due course, they may spawn divergent substantive protections as well. This discussion does not just have an academic character, but has major practical consequences for

\footnotetext{
${ }^{14}$ Follesdal and Ulfstein (2018). See recently also on the contribution of general principles to the coherence of international law (Andenas et al. 2019).

15 Court of Justice of the EU 6 March 2018, Case C-284/16, Slovak Republic v. Achmea BV, ECLI:EU:C:2018:158.

${ }^{16}$ Case C-402/05 P and C-415/05, P. Kadi and Al Barakaat International Foundation v. Council and Commission [2008] ECR I-6351. See for a discussion from a constitutional perspective: Kokott and Sobotta (2012).
} 
investors, who may not trust the constitutional guarantees offered by domestic dispute resolution procedures, even if they are EU-supervised. ${ }^{17}$

At a more fundamental level, the question arises whether particular fields of law are truly constitutionalizing, regardless of the scholarly use of the term 'global constitutionalism'. Examining the same field, David Haljan, a constitutional lawyer, subjects international investment law to a rigorous public law analysis, and concludes that investment law cannot (yet) be considered as a constitutional system, as it is not supported by a community and a body of shared values and principles. According to Haljan, merely creating institutions that deny the social character of the law cannot do the trick. While not offering ready-made solutions, he nevertheless invites us to further define the community of interests which is served by foreign investment, as well as the fundamental values governing international investment protection and arbitration.

An equally sceptical approach can be found in the article of Astrid Kjeldgaard-Pedersen on the international legal personality of the individual in light of global constitutionalism. Kjeldgaard-Pedersen takes as her point of departure the global constitutionalist claim that the individual is the ultimate subject of international law. Arguably, at least for constitutionalist scholars, this has led to a fundamental change in the structure of the international legal system. Kjeldgaard-Pedersen forcefully refutes these 'normative' arguments from a historical-empirical perspective, pointing out that international rights and duties have been bestowed on individuals for a very long time, even predating World War II. She argues that the international legal system has never presumed (a priori) a particular legal personality for individuals; instead, international law has derived such personality from the interpretation of international legal norms. Kjeldgaard-Pedersen ultimately appears to warn us not to mistake the expansion of issues governed by international law for the constitutionalization of international law: non-state actors do not necessarily have an enhanced legal status, nor are international and domestic law evolving towards a monist relationship.

By presenting these perspectives, the Netherlands International Law Review hopes to trigger renewed debate on the reality, benefits and blind spots of global constitutionalism as an intellectual construct to behold and understand contemporary international law.

\section{References}

Alvarez JE (2006) International organizations as law-makers. Oxford University Press, Oxford Andenas M, Fitzmaurice M, Tanzi A, Wouters J (eds) (2019) General principles of law and the coherence of international law. Brill, Leiden

\footnotetext{
17 'Why the European Union should not ditch bilateral investment treaties', The Economist, 6 June 2019 (arguing that, with populist corrupting courts, notably in Central and Eastern Europe, foreign investors need adequate safeguards).
} 
Benvenisti E (2007) The conception of international law as a legal system. German Yearb Int Law 50:393-405

Cassese S (2005) Administrative law without the state? The challenge of global regulation. NY Univ J Int Law Polit 37:663-694

de Wet E, Vidmar J (eds) (2012) Hierarchy in international law. The place of human rights. Oxford University Press, Oxford

Duquet S, Wouters J (2014) Non-traditional norms in international law: approaches in legal scholarship. Czech Yearb Public Private Int Law 5:3-21

Fassbender B (2016) International constitutional law: written or unwritten? Chin J Int Law 15:489-515

Follesdal A, Ulfstein G (2018) The judicialization of international law. A mixed blessing?. Oxford University Press, Oxford

Follesdal A, Wessel RA, Wouters J (eds) (2008) Multilevel regulation and the EU. The interplay between global, European and national normative processes. Martinus Nijhoff Publishers, Leiden

Joerges C, Petersmann EU (eds) (2006) Constitutionalism, multilevel trade governance and social regulation. Hart, Oxford

Kingsbury B, Krisch N, Stewart RB (2005) The emergence of global administrative law. Law Contemp Probl 68:15-61

Klabbers J, Peters A, Ulfstein G (2009) The constitutionalization of international law. Oxford University Press, Oxford

Kokott J, Sobotta C (2012) The Kadi case-constitutional core values and international law-finding the balance? Eur J Int Law 23:1015-1024

Krisch N (2010) Beyond constitutionalism: the pluralist structure of postnational law. Oxford University Press, Oxford

Oldani C, Wouters J (eds) (2018) The G7, anti-globalism and the governance of globalization. Routledge, London

Pauwelyn J, Wessel RA, Wouters J (eds) (2012) Informal international lawmaking. Oxford University Press, Oxford

Pauwelyn J, Wessel RA, Wouters J (2014) When structures become shackles: stagnation and dynamics in international lawmaking. Eur J Int Law 25:733-763

Peters A (2006) Compensatory constitutionalism: the function and potential of fundamental international norms and structures. Leiden J Int Law 19:579-610

Peters A (2008) Humanity as the $A$ and $\Omega$ of sovereignty. Eur J Int Law 30:513-545

Schwöbel C (2011) Global constitutionalism in international legal perspective. Martinus Nijhoff, Leiden Talmon S (2005) The Security Council as world legislature. Am J Int Law 99:175-193

von Bogdandy A et al (eds) (2010) The exercise of public authority by international institutions: advancing international institutional law. Springer, Heidelberg

von Bogdandy A, Goldmann M, Venzke I (2017) From public international to international public law: translating world public opinion into international public authority. Eur J Int Law 28:115-145

Publisher's Note Springer Nature remains neutral with regard to jurisdictional claims in published maps and institutional affiliations. 